\title{
Kajian Tarif Angkutan Pedesaan Trayek Terminal Kota Ruteng - Satar Mese
}

\author{
Mansuetus Gare ${ }^{1}, *$ Mikael Wora ${ }^{2}$ \\ ${ }^{1,2}$ Program Sudi Teknik Sipil, Fakultas Teknik, Universitas Flores, Ende \\ *) Correspondence email : ata_kelisoke@yahoo.co.id
}

\begin{abstract}
ABSTRAK
Penelitian ini ingin menunjukkan besar tarif normal yang layak berdasarkan situasi dan kondisi saat ini. Hasil yang diperoleh BOK sebesar Rp.222.900,00 /hari/ trip, maka tariff rata-rata sebesar Rp. 12.800,00 sedangkan tariff berdasarkan Perda sebesar Rp. 13.464,00. Namun Tarif real dilapangan variasi yaitu Rp. 15.000,00 Rp. $18.000,00$ dan $R p$ 20.000,00. Kemauan masyarakat membayar angkutan antara Rp 10.000 sampai Rp 20.000 dengan rata-rata $R p$ 12.300,00 masih dalam batas normal, Sedangkan berdasarkan analisis dari biaya yang di keluarkan setiap kali kendaraan beroperasi yaitu sebesar Rp 18.600,00 masih jauh dari tarif tetapan pemerintah daerah yaitu sebesar Rp 13.500,00. Kemampuan membayar untuk transportasi faktual rata-rata Rp 12.300,00 Sedangkan kemampuan membayar terendah dari masyarakat sebesar Rp 10.000,00 dan kemampuan membayar masyarakat tertinggi sebesar Rp 20.000,00. Kemauan membayar tarif dari masyarakat di Ruteng dan Kecamatan Satar Mese rata-rata Rp 12.800,00 Sedangkan kemauan membayar tarif terendah sebesar Rp 10.000,00 dan kemauan membayar tarif tertinggi sebesar Rp 20.000,00. Berdasarkan analisis data pengeluaran kendaraan tiap kali beroprasi, tarif angkutan umum jurusan kota Ruteng - Satar Mese yang efektif perhari yaitu sebesar Rp 18.600,00/pnp/rit.
\end{abstract}

Kata Kunci : Trayek pedesaan, Tarif angkutan, Kemampuan membayar, Kemauan membayar

\section{LATAR BELAKANG}

Berdasarkan fenoena yang terjadi Penetapan tarif angkutan pedesaan jurusan Ruteng - Satar Mese oleh pemilik jasa angkutan dipengaruhi karena kenaikan harga bahan bakar minyak (BBM). Biaya ini Sejak tahun 2014 tarif angkutan sebesar Rp 15.000,00 . kemudian tahun 2015 sebesar Rp 18.000,00 dan tahun 2016 sebesar Rp 20.000,00 dan telah melampaui tari resmi yang ditetapkan oleh Pemda berdasarkan Peraturan daerah Kabupaten Manggarai tahun 2014 tentang tarif jarak trayek angkutan pedesaan Ruteng Satar Mese sebesar Rp Rp 13.464,00. Dalam penetapan harga tarif angkutan sering terjadi konflik antara pengguna jasa pengusaha jasa angkutan pedesaan. Jarak antara Ruteng - Satar Mese adalah 34,90 km ke arah selatan. jenis kendaraan yang beroperasi adalah mini bus jumlah awalnya adalah 10 unit. Bersamaan dengan naiknya Bahan Bakar Minyak (BBM) pada tahun 2014, berpengaruh terhadap perubahan tarif, sehingga sejumlah kendaraan melakukaan mogok untuk tidak beroperasi. Menurut pengakuan pemilik kendaraan, mereka merasa dirugikan dengan penetapan tarif yang tidak memberikan keuntungan yang maksimal. Maka jumlah kendaraan yang aktif beroperasi sampai saat ini 7 unit. Penelitian ini kendaraan dengan sampel berjumlah 5 unit. Kecamatan Satar Mese dengan ibu kotanya Iteng terletak di bagian selatan Kabupaten Manggarai, dan merupakan daerah pertanian dan pariwisata. Pembagian wilayah administrasi pemerintahan terdiri dari 11 Desa denganluas wilayah $537 \mathrm{~km}^{2}$ dan dengan jumlah penduduk 33.017 jiwa, hal ini sangat mempengaruhi pergerakan angkutan perdesaan antara satu kecamatan dengan kecamatan lain, disebabkan oleh sarana pertanian, pariwisata dan perilaku ekonomi. Sedangkan Kota Ruteng adalah ibu kota dari kabupaten Manggaraiyang merupakan pusat Pemerintahan kabupaten Manggarai dan juga kota pendidikan dengan pembagian administrasi yang terdiri dari 12 kecamatan. Kota Ruteng terdiri dari 8 kelurahan dengan luas wilayah $892 \mathrm{~km}^{2}$ dan populasi jiwa 484.015 jiwa.Tujuan penelitian ini untuk menacari tahu apakah tarif angkutan pedesaan Ruteng-Satar Mese yang ditetapkan oleh peda masih layak atau tidak?

\section{Transportasi}

Pengertian transportasi menurut Morlok (1978) adalah kegiatan memindahkan atau mengangkut sesuatu dari satu tempat ketempat lain. Menurut Bowersox (1981), transportasi adalah perpindahan barang atau penumpang dari satu tempat ke tempat lain, dimana produk dipindahkan ke tempat tujuan dibutuhkan. 
Menurut Setijowarno dan Frazila (2001), pergerakan orang dan barang dari satu tempat ke tempat yang lainnya mengikuti tiga kondisi yaitu : Perlengkapan, relatif menarik antara dua tujuan atau lebih; Keinginan untuk mengatasi jarak, dimana sebagai perpindahan yang diukur dalam kerangka waktu dan ruang yang dibutuhkan untuk mengatasi jarak dan teknologi terbaik untuk mencapainya; Kesempatan intervensi berkompetisi di antara beberapa lokasi untuk memenuhi kebutuhan dan penyediaan.

\section{Angkutan Umum Penumpang}

Angkutan menurut UU No 22 Tahun 2009 tentang Lalu lintas dan Angkutan Umum adalah pemindahan orang atau barang dari satu tempat ke tempat yang lain dengan menggunakan kendaraan. Angkutan umum penumpang menurut Warpani (1990) adalah angkutan penumpang yang dilakukan dengan sistem sewa atau bayar, Termasuk dalam pengertian angkutan umum penumpang adalah angkutan kota maupun pedesaan (bus, minibus, kereta api, angkutanp air dan angkutan udara). Tujuan utama angkutan umum penumpang adalah : Menyelenggarakan pelayanan angkutan yang baik dan layak bagi masyarakat yaitu aman, cepat, murah dan nyaman; Membuka lapangan kerja; Pengurangan volume lalu lintas kendaraan pribadi

\section{Tarif Angkutan}

Menurut Matz dan Usry (1975), tarif didefinisikan sebagai besaran moneter yang harus dikompensasikan oleh pihak-pihak yang menggunakan jasa pelayanan atau yang mengonsumsi suatu produk. Secara ilmu ekonomi tarif biasanya terbentuk sebagai interaksi antara produsen dan konsumen, dimana aspek keseimbangan antara pasokan (supply) dan sediaan (demand) berperanan penting. Ditinjau dari angkutan umum tarif adalah besaran moneter yang harus dikeluarkan pengguna jasa (penumpang) untuk mendapatkan jasa pelayanan yang diberikan oleh operator. Menurut Muchtarudin Siregar 1990, memberi pengertian tarif angkutan umum merupakan biaya yang harus dibayar oleh pengguna jasa angkutan umum atas fasilitas yang diterima sesuai dengan harga yang dikeluarkan oleh operator yang menyediakan jasa angkutan umum tersebut.

Menurut Muctarudin (1990), ada tiga pihak yang berkepentingan dalam menentukan besar tarif, tarif mempunyai arti yang berbeda bagi tiga pihak tersebut yaitu:

1. Penyediaan jasa transportasi (operator), tarif adalah harga dari jasa yang diberikan.

2. Pengguna jasa angkutan (user), tarif adalah biaya yang harus dikeluarkan setiap kali menggunakan kendaraan tersebut baik untuk bepergian atau mengirimkan barang dari suatu tempat ke tempat lain.

3. Pemerintah (regulator), sebagai pihak yang menentukan tarif resmi, besarnya tarif yang berlaku akan sangat mempengaruhi besarnya pengeluaran dan pendapatan daerah pada sektor angkutan yang bersangkutan

Menurut Suwardjoko Wardani (1990), untuk melindungi konsumen, Pemerintah menetapkan batas tarif maksimum dan batas tarif minimum hal ini untuk menjaga persaingan yang sehat, dan masih memberi keuntungan yang wajar kepada pengusaha angkutan pedesaan.

\section{Sistem Penentuan Tarif Jasa Transportasi}

Menurut Abbas Salim (1998), penentuan tarif dapat didasarkan salah satu dari pada biaya operasi, nilai jasa angkutan dan volume angkutan, kemudian dikelompokkan sebagai berikut:

1. Sistem pembentukan tarif atas dasar jasa transportasi (cost of service pricing):

2. Sistem pembentukan tarif atas dasar nilai jasa transportasi (value service pricing)

3. Sistem pembentukan tarif atas dasar "What the traffict will bear"

Dari ketiga pendekatan tarif yang berlaku, perhitungan berdasarkan biaya operasional pengadaan angkutan umum yang sesuai dengan kondisi saat ini.

\section{Sistem Tarif Angkutan Umum}

Menurut Suwardjoko Warpani (1990), tarif adalah biaya yang dibayarkanoleh pengguna jasa angkutan umum per satuan berat penumpang per kilometer. penetapan ini tarif dimaksudkan untuk mendorong 
terciptanya penggunaan dan saran perangkutan secara optimum dengan mempertimbangkan lintas yang bersangkutan.

Tarif angkutan umum penumpang merupakan hasil perkalian antara biaya satuan dengan jarak $(\mathrm{km})$ ratarata satuan perjalanan, ditambah $10 \%$ untuk jasa keuntungan pengusaha (Direktorat Jenderal Perhubungan Darat, 1999).

$$
\text { Tarif }=(\text { Biaya Satuan } x \text { Jarak rata-rata })+10 \%
$$

Beberapa alternatif yang umumnya digunakan untuk menentukan sistem tarik angkutan umum:

1. Tarif Seragam (Flat Fare)

Pada sistem tarif ini, dikenakan tanpa memperhatikan jarak yang ditempuh, sistem ini akan memberikan keuntungan:

a. Kemudahan dalam pengumpulan ongkos di dalam kendaraan sehingga memungkinkan transaksi yang cepat terutama untuk kendaraan berukuran besar dan dioperasikan oleh satu orang.

b. Memudahkan pemeriksaan karcis penumpang dan persediaan karcis.

2. Tarif Berdasarkan Jarak (Distance Based Fare)

Pada sistem tarif ini dibedakan berdasarkan jarak yang ditempuh. Perbedaan tarif didasarkan pada satuan kilometer, tahapan dan zona.

a. Tarif Berdasarkan Kilometer

b. Tarif Berdasarkan Tahapan

c. Tarif Berdasarkan Zona

\section{Keseimbangan Tarif Angkutan Pedesaan}

Menurut Morlok (1978), teori keseimbangan tarif angkutan umum adalah terori keseimbangan antara penawaran (supply) dan permintaan (demand) dalam teori keseimbangan pasar ekonomi. Dalam teori ini keseimbangan tarif angkutan umum, supply (fungsi penawaran) dianologikan pada tarif angkutan umum ditetapkan pemerintah dan fungsi permintaan (demand) dianalogikan pada Ability To Pay dan Willingness To Pay pengguna jasa angkutan umum.

\section{Karakteristik Pelaku Perjalanan (Pengguna Jasa Angkutan Umum)}

Faktor penting yang termasuk dalam kategori ini adalah yang berkaitan dengan ciri sosial - ekonomi pelaku perjalanan, termasuk tingkat penghasilan, kepemilikan kendaraan, struktur dan besarnya keluarga, kerapatan pemukiman, macam pekerjaan, dan lokasi tempat pekerjaan (Bruton,1975,172)

1. Penghasilan

2. Kepemilikan Kendaraan

3. Kerapatan Pemukiman

4. Faktor Sosial Ekonomi

5. Faktor status sosial

\section{Penentuan Besaran Tarif}

Salah satu cara yang harus ditempuh dalam menetapkan kebijakan penentuan besaran tarif adalah dengan menentukan terlebih dahulu tujuan kebijakan tersebut. Besaran tarif yang ditetapkan haruslah dilandasi dengan perhitungan biaya pokok produksi persatuan unit output dan sesuai dengan kemauan dan kemampuan masyarakat untuk membayar (willingness to pay dan ability to pay). Apabila kedua nilai ini sudah dikemukakan maka besaran tarif yang hendaknya ditetapkan sedemikian sehingga besarnya di atas biaya pokok produksi persatuan output dan tidak melebihi kemampuan membayar dari masyarakat penggunanya.

Penetapan tarif di atas biaya produksi per satuan output merupakan kebijaksanaan yang memperhatikan kesejahteraan pihak operator sebagai penyedia dan pemberi jasa angkutan. Menurut Hayati (2000), dengan memperhatikan parameter biaya pokok produksi (BPP) dan parameter willingness to pay (WTP) pada dasarnya ada tiga kemungkinan yang dapat terjadi, yaitu:

a. Nilai WTP berada cukup jauh diatas nilai BPP.

b. Nilai WTP sangat dekat dengan nilai BPP tetapi masih berada di atasnya. 
c. Nilai WTP berada cukup Jauh di bawah nilai BPP.

\section{Biaya Operasi Kendaraan (BOK)}

Biaya operasi kendaraan (BOK) adalah biaya yang secara ekonomi terjadi karena dioperasikannya satu kendaraan pada kondisi normal untuk satuan tujuan tertentu. Daniel (1974), mengemukakan bahwa biaya operasi kendaraan biasanya dibagi dalam dua kelompok, yaitu biaya tetap (fixed cost) dan biaya tidak tetap atau biaya variabel (variable cost), selain kedua kelompok tersebut, ada satu jenis biaya yang sering dipakai untuk perhitungan biaya operasional kendaraan yaitu biaya overhead.

\section{Biaya Operasional Kendaraan}

Daniels (1974), mengemukakan bahwa sistem ini merupakan hubungan antara pengusaha sebagai pemilik armada kendaraan dengan sopir sebagai partner kerja, dimana pihak sopir mempunyai kewajiban memberi setoran uang dengan jumlah tertentu kepada pemilik kendaraan setiap kali kendaraan dioperasikan.

\section{Produksi Pelayanan Jasa Angkutan}

Menurut Morlok (1998), untuk mengukur besaran produksi pelayanan angkutan umum dapat ditinjau dari beberapa alternatif (unit), yaitu: Seat-Kilometer, Penumpang-Kilometer dan Penumpang-trip.

\section{Penumpang-Kilometer.}

Besaran penumpang-kilometer menunjukkan besaran faktual dari tingkat okupasi serta panjang trip dari penumpang. Dalam perhitungan besaran ini kita akan mengenal suatu grafik yang menggambarkan besar kecilnya jumlah penumpang dalam suatu kendaraan tiap tiap perhentian dalam satu trip perjalanan, grafik ini biasa disebut sebagai grafik profil pengisian angkutan (loading profile).

\section{Biaya Pokok Produksi Jasa Angkutan}

Biaya pokok produksi jasa angkutan didefinisikan sebagai besarnya biaya yang harus dikeluarkan oleh pihak operator dalam kaitannya untuk menghasilkan satuan produksi pelayanan umum yang dapat disediakan.

\section{Dimana:}

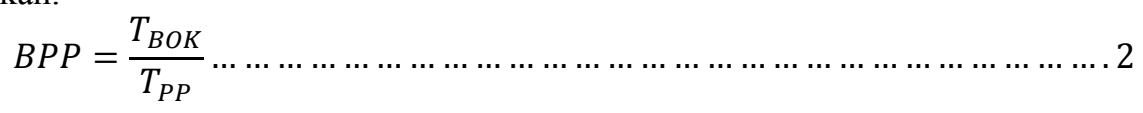

$$
\begin{aligned}
& \mathrm{BPP}=\text { Biaya pokok produksi pelayanan }(\mathrm{Rp} / \mathrm{Pnp}-\mathrm{Km}) \\
& \mathrm{T}_{\mathrm{BOK}}=\text { Total biaya operasional kendaraan persatuan waktu }(\mathrm{Rp}) \\
& \mathrm{T}_{\mathrm{PP}}=\text { Total Produksi pelayanan persatuan waktu (pnp-Km) }
\end{aligned}
$$

Untuk melakukan perhitungan biaya pokok pada Mini Bus dapat digunakan pedoman pada Tabel 1.

\section{Biaya Overhead}

David Lowe (1989) menyatakan, bahwa menghitung biaya overhead ini, beberapa peneliti melakukan dengan dua cara, yaitu :

a. Menghitung $20 \%-25 \%$ dari jumlah biaya tidak tetap dan biaya tetap

b. Menghitung biaya overhead secara terperinci

David Lowe juga menyebutkan beberapa komponen dari biaya tetap overhead yang dapat diamati yaitu biaya untuk : Pengelolaan, Kantor dan administrasi, Bengkel dan took, Depot cabang. Pemasaran dan iklan, Armada tambahan, Pelayanan profesional. 
Tabel 1. Tabel Pedoman Teknis Kendaraan Angkutan Pedesaan

\begin{tabular}{|c|c|c|c|c|c|}
\hline \multirow{2}{*}{$\mathbf{0}$} & \multirow{2}{*}{ Uraian } & \multirow{2}{*}{ satuan } & \multicolumn{3}{|c|}{ Angkutan pedesaan } \\
\hline & & & \multicolumn{2}{|c|}{ Bus besar } & Bus sedang \\
\hline & renyusutan kendaraan & Tahun & 5 & 5 & 5 \\
\hline & zmpuh rata-rata & $\mathrm{Km} /$ hari & 250 & 250 & 250 \\
\hline & bakar minyak & $\mathrm{Km} / \mathrm{hri}$ & 2 & $3.6-3$ & 5 \\
\hline & anti ban 3 & $\mathrm{Km}$ & 24.000 & 21.000 & 20.000 \\
\hline & Iengemudi/bus & Org/kend & 1,2 & 1,2 & 1,2 \\
\hline & ondektur/bus & Org/kend & 1,2 & 1,2 & 1,2 \\
\hline & əmpuh antara service kecil & $\mathrm{Km}$ & 5.000 & 5.000 & 4.000 \\
\hline & adang atau service besar & $\mathrm{Km}$ & 10.000 & 1.0000 & 10.000 \\
\hline & Itian minyak motor & $\mathrm{Km}$ & 4.000 & 4.000 & 4.000 \\
\hline 0 & Penggatian minyak rem & $\mathrm{Km}$ & 8.000 & 8.000 & 8.000 \\
\hline 1 & Penggatian gemuk & $\mathrm{Km} / \mathrm{kg}$ & 3.000 & 3.000 & 3.000 \\
\hline 2 & Penggatian minyak rem & $\mathrm{Km}$ & 12.000 & 12.000 & 12.000 \\
\hline 3 & Penggatian minyak persneling & $\mathrm{Km}$ & 12.000 & 12.000 & 12.000 \\
\hline 4 & Hari jalan siap operasi & Hri/thn & 365 & 365 & 365 \\
\hline 5 & SO : SGO & $\%$ & 80 & 80 & 80 \\
\hline 6 & Nilai residu & $\%$ & 20 & 20 & 20 \\
\hline
\end{tabular}

Sumber : Pedoman teknis departemen perhubungan ,2002

\section{Ability To Pay (ATP)}

Menurut Button (1982), ability to pay (ATP) adalah kemampuan seseorang untuk membayar jasa pelayanan yang diterimanya berdasarkan penghasilan yang dianggap ideal. Pendekatan yang digunakan dalam ATP didasarkan pada alokasi biaya untuk transportasi dan intensitas perjalanan pengguna. Besar ATP merupakan rasio budget transportasi dan intensitas perjalanan. Faktor-faktor yang mempengaruhi ATP adalah: penghasilan keluarga perbulan, alokasi dana transportasi, intensitas perjalanan, dan jumlah anggota keluarga.

ATP dihitung dengan menggunakan metode Household Budget (anggaran belanja rumah tangga), dimana dasar yang digunakan adalah total pendapatan responden dan besarnya alokasi dana untuk transportasi.

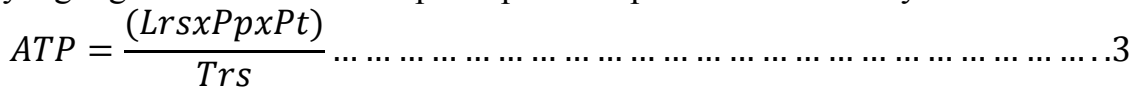

Dimana:

$$
\begin{aligned}
& \mathrm{Lrs}=\text { Pendapatan responden per bulan }(\mathrm{Rp} / \mathrm{bulan}) \\
& \mathrm{Pp}=\text { Persentase pendapatan untuk transportasi/bulan } \\
& \mathrm{Pt}=\text { Persentase dari proporsi biaya transportasi, pengguna angkutan sejenis. } \\
& \mathrm{Trs}=\text { Total panjang perjalanan responden per bulan }(\mathrm{Km} / \mathrm{bulan})
\end{aligned}
$$

\section{Willingness To Pay (WTP)}

Button (1982) mendefinisikan willingness to pay (WTP), sebagai besaran rupiah rata-rata yang ingin masyarakat keluarkan sebagai pembayaran satu unit pelayanan angkutan umum yang dinikmatinya. Besar WTP masyarakat terhadap angkutan umum dipengaruhi oleh kondisi ekonomi masyarakat. Analisis WTP didasarkan pada persepsi pengguna terhadap tarif dari jasa pelayanan angkutan umum yang mempengaruhi oleh: kuantitas dan kualitas produksi jasa angkutan umum, utilitas pengguna, penghasilan pengguna angkutan.

Perhitungan besarnya willingness to pay (WTP) didasarkan pada panjang perjalanan responden dengan angkutan transportasi $(\mathrm{Km})$ dan persepsi responden tentang biaya $(\mathrm{Rp})$ perjalanan tersebut kemudian membagikan biaya tersebut dengan panjang perjalanan yang dilakukan $(\mathrm{Rp} / \mathrm{Km})$. 


\section{Average Trip Length (ATL)}

Average trip length (ATP) adalah suatu studi yang dilakukan untuk dapat mengetahui panjang jalan jarak perjalanan rata-rata yang ditempuh. Pada dasarnya perhitungan average trip length (ATL) adalah jumlah dari perkalian volume dengan panjang jarak tempuh kendaraan, sehingga dapat dirumuskan sebagai berikut:

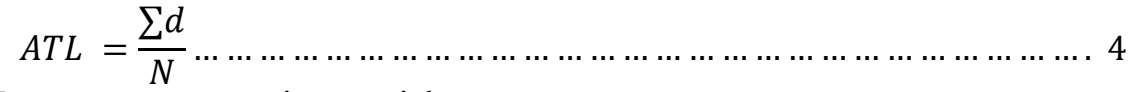

$$
\begin{aligned}
& \text { Dimana: ATL }=\text { panjang perjalanan rata-rata } \\
& \begin{array}{ll}
\sum_{\mathrm{N}}= & \text { jumlah jarak tempuh dari semua kendaraan } \\
\mathrm{N}= & \text { jumlah kendaraan }
\end{array}
\end{aligned}
$$

\section{METODE}

\section{Tempat dan Waktu Peneliti}

Penelitian dilaksanakan di wilayah kabupaten Manggarai ( Ruteng - Satar Mese).

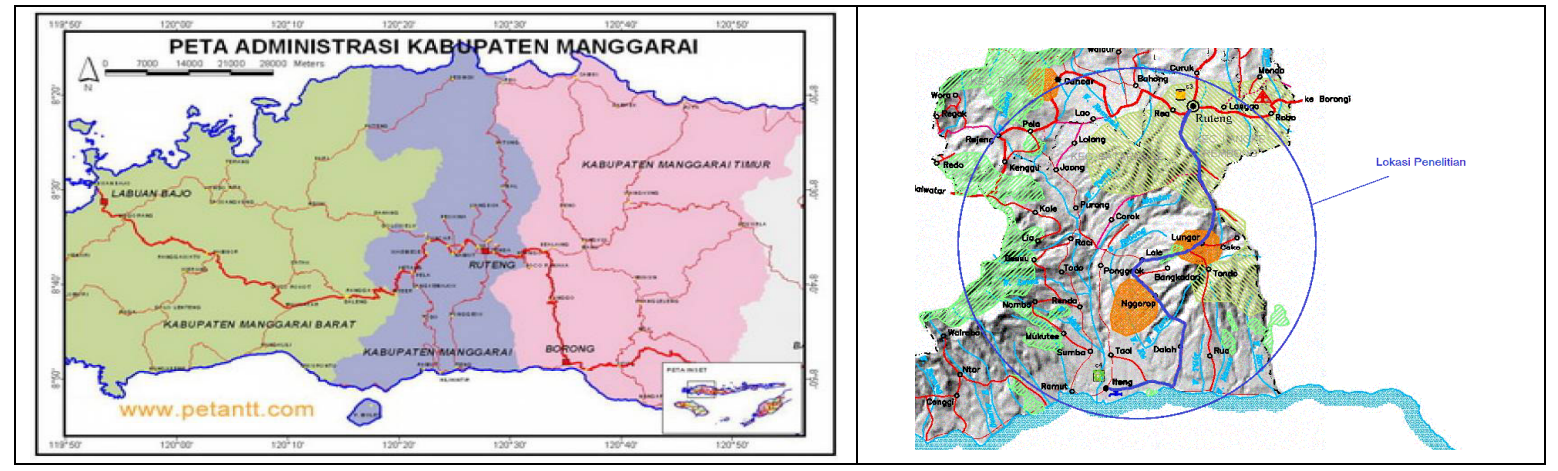

Gambar 1. Peta kabupaten manggarai dan Peta lokasi penelitian

\section{Diagram Alir Penelitian}

Struktur penelitian dapat di lihat dalam diagram alir penelitian sesuai Gambar :

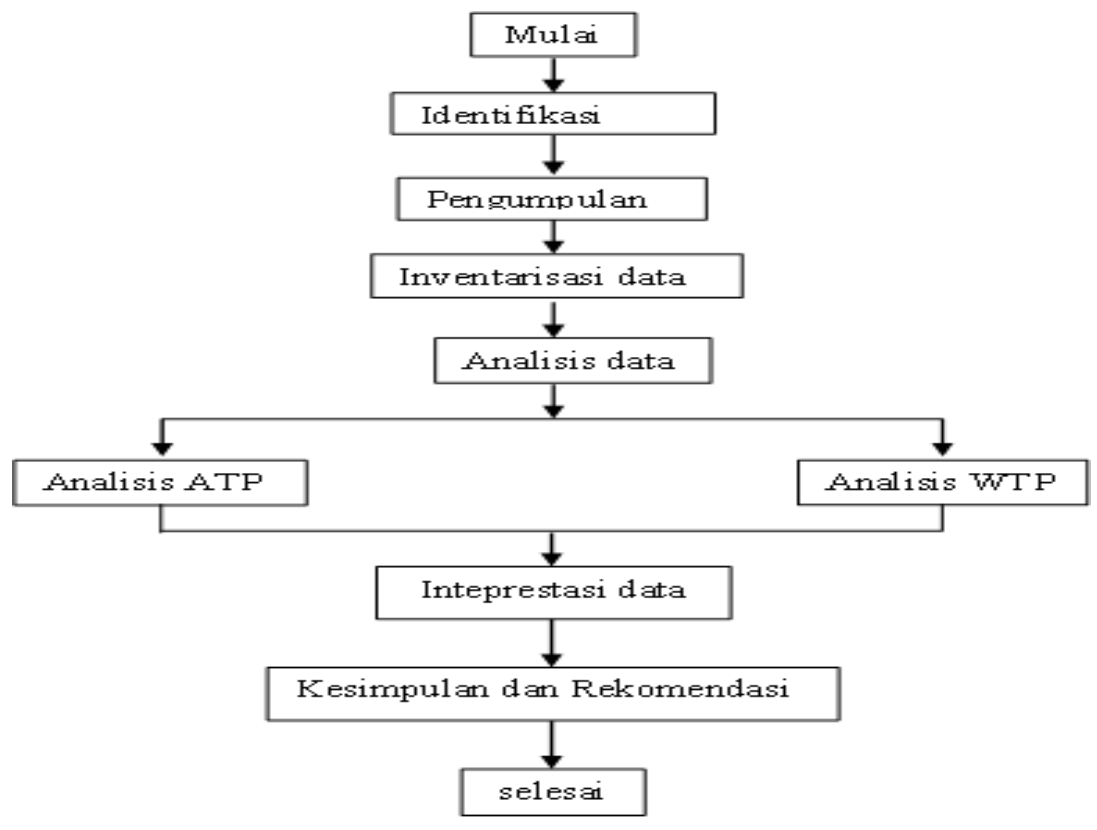

Gambar 2. Bagan alir Peneltian 


\section{HASIL DAN PEMBAHASAN}

Lokasi yang menjadi target penelitian yaitu kabupaten Manggarai (rute kota Ruteng-Satar Mese) yang terdiri dari 7 (tujuh) Desa/kelurahan. Data-data primer yang diambil meliputi: data panjang perjalanan, penghasilan keluarga, data WTP, pengguna angkutan umum, tujuan perjalanan dan data lainnya yang dibutuhkan untuk analisa.

Pendeskripsian data primer hasil survei di Kecamatan Satar Mese selengkapnya dapat dilihat pada tabel berikut:

1. Daerah / Lokasi Penelitian Ruteng - Satar Mese

Tabel 2. Lokasi Survei di terminal Ruteng - Satar Mese ( Puni )

\begin{tabular}{llcc}
\hline No. Lokasi & $\begin{array}{c}\text { Julah Sampel } \\
\text { Penumpang (Orang) }\end{array}$ & $\begin{array}{c}\text { Panjang Perjalanan } \\
\text { (orang/bulan/km) }\end{array}$ & Rp/bulan \\
\hline Desa Ponggeok & 2 & 234 & 3.510 .000 \\
Desa Lungar & 4 & 78 & 1.560 .000 \\
Kel Pau & 2 & 117 & 2.160 .000 \\
Kec Ruteng & 3 & 156 & 3.120 .000 \\
Kec Langke Rembong & 2 & 78 & 3.900 .000 \\
Kec Satar Mese Barat & 4 & 195 & 1.404 .000 \\
\hline \multicolumn{1}{c}{ Jumlah } & $\mathbf{1 7}$ & $\mathbf{2 . 4 9 6}$ & $\mathbf{1 5 . 6 0 0 . 0 0}$ \\
\hline
\end{tabular}

Sumber: Hasil Survei, 2016

Tabel 3. Lokasi Survei di terminal Satar Mese - Ruteng ( Iteng )

\begin{tabular}{clccc}
\hline No. & \multicolumn{1}{c}{ Lokasi } & $\begin{array}{c}\text { Julah Sampel } \\
\text { Penumpang (orang) }\end{array}$ & $\begin{array}{c}\text { Panjang Perjalanan } \\
\text { (orang/bulan/km) }\end{array}$ & Rp/bulan \\
\hline 1 & Desa Lunggar & 2 & 78 & 2.340 .000 \\
2 & Desa Umum & 4 & 156 & 1.560 .000 \\
3 & Desa Paka & 2 & 156 & 702.000 \\
4 & Desa Golo Mocong & 3 & 39 & 3.120 .000 \\
5 & Desa Ponggeok & 2 & 156 & 3.900 .000 \\
6 & Kec. Satar Mese Barat & 4 & 195 & 1.404 .000 \\
\hline & Jumlah & $\mathbf{1 7}$ & $\mathbf{2 . 0 7 2}$ & $\mathbf{1 3 . 0 2 6 . 0 0}$ \\
\hline
\end{tabular}

Sumber: Hasil Survei, 2016

2. Data Faktual Panjang Perjalanan penumpang dalam satu bulan

Tabel 4. Data Faktual Panjang perjalanan penumpang dalam satu bulan

\begin{tabular}{cccccc}
\hline No & $\begin{array}{c}\text { Total Panjang Perjalanan } \\
\text { (km/bulan/kk) }\end{array}$ & No & $\begin{array}{c}\text { Total Panjang } \\
\text { Perjalanan } \\
\text { (km/bulan/kk) }\end{array}$ & No & $\begin{array}{c}\text { Total Panjang } \\
\text { Perjalanan } \\
\text { (km/bulan/kk) }\end{array}$ \\
\hline 1 & 78 & 13 & 156 & 25 & 195 \\
2 & 78 & 14 & 78 & 26 & 78 \\
3 & 156 & 15 & 156 & 27 & 78 \\
4 & 117 & 16 & 234 & 28 & 78 \\
5 & 156 & 17 & 234 & 29 & 78 \\
6 & 195 & 18 & 156 & 31 & 156 \\
7 & 195 & 19 & 156 & 32 & 156 \\
8 & 195 & 21 & 756 & 33 & 156 \\
9 & 156 & 22 & 78 & 34 & $\mathbf{4 . 5 6 8}$ \\
10 & 156 & 23 & 39 & & 78 \\
11 & 156 & 24 & 39 & & \\
\hline
\end{tabular}

Sumber: Hasil Survei, 2016

3. Penghasilan Keluarga di Wilayah Kecamatan Satar Messe 
Tabel 5. Data Faktual Penghasilan Keluarga

\begin{tabular}{cc}
\hline Pendapatan Keluarga (Rp) & Frekuensi \\
\hline Rp 750.000 - Rp 1.000.000 & 12 \\
Rp 1.000.000 - Rp 1.500.000 & 11 \\
Rp 1.500.000 - Rp 2.000.000 & 3 \\
Rp 2.000.000 - Rp 2.500.000 & 2 \\
Rp 2.000.000 - Rp 3.000.000 & 5 \\
. Rp 3.000.000 & 1 \\
\hline Jumlah & 34
\end{tabular}

4. Data kemauan Membayar (WTP)

Tabel 6. Data Faktual Kemauan Membayar

\begin{tabular}{ccc}
\hline No & Persepsi Tarif & Frekuensi \\
\hline 1 & 10.000 & 15 \\
2 & 12.000 & 5 \\
3 & 13.000 & 4 \\
4 & 15.000 & 5 \\
5 & 20.000 & 5 \\
\hline & Jumlah & 34 \\
\hline
\end{tabular}

Sumber: Hasil Survei, 2016

5. Data Pengeluaran Kendaraan

Tabel 7. Data Faktual Pengeluaran kendaraan

\begin{tabular}{cccc}
\hline No. Polisi & Total BOK Perhari & Kapasitas Penumpang & Tarif Efektif \\
\hline EB 8173 N & Rp 218.829,-- & 12 orang & Rp.18.583,-- \\
EB 2822 N & Rp 222.000,- & 12 orang & Rp.18.526,-- \\
EB 2843 N & Rp 222.996,- & 12 orang & Rp. 18.583,- \\
EB 2392 N & Rp 231.787,-- & 12 orang & Rp. 19.315,- \\
EB 2758 N & Rp 215.805,-- & 12 orang & Rp. 17.983,- \\
EB 2359 N & Rp 225.718,-- & 12 orang & Rp. 18.809,- \\
EB 7051 N & Rp 218.829,- & 12 0rang & Rp. 18.235,- \\
\hline
\end{tabular}

Sumber: Hasil Survei, 2016

3. Penetapan Tarif Resmi

Penetapan tarif angkutan kota dalam di kabupaten Manggarai sesuai dengan Surat Keputusan Bupati Manggarai nomor 36 tahun 2014 Tentang Penetapan Tarif Angkutan Penumpang di darat dalam wilayah Kabupaten Manggarai adalah:

a. Tarif Angkutan Penumpang Umum jurusan pedesaan Ruteng Satar Messe (Puni-Iteng) untuk masyarakat Umum sebesar

Rp 13.464,00/penumpang/ret. Dari hasil perhitungan di atas dapat disimpulkan bahwa jumlah yang harus disurvei adalah 70 penumpang, dari survei pendahuluan ada sebanyak 34 Responden data maka untuk memenuhi kecukupan data penelitian ini maka perlu ditambah 36 data. 
Tabel 8. Data Uji Kecukupan Data

\begin{tabular}{cccc}
\hline Responden & $\begin{array}{c}\text { Penghasilan } \\
(\mathbf{R P} / \mathbf{B l n} / \mathbf{k k})\end{array}$ & $\begin{array}{c}\text { Panjang Perjalanan } \\
(\mathbf{K m} / \mathbf{B l n} / \mathbf{k k})\end{array}$ & $\begin{array}{c}\text { WTP } \\
(\mathbf{R p})\end{array}$ \\
\hline 34 & 52.170 .000 & 4602 & 435.000 \\
Rata-rata & 1.534 .412 & 135.35 & 12,794 \\
Maksimum & 3.500 .000 & 234 & 20.000 \\
Minimum & 800.000 & 39 & 10.000 \\
\hline
\end{tabular}

Sumber: Hasil Survei, 2016

\section{Biaya Operasional Kendaraan (BOK)}

Untuk mengetahui besaran biaya operasional kendaraan diperlukan analisa hubungan kerja antara pengusaha dan sopir. Hal ini untuk mengetahui beban-beban biaya yang nantinya berpengaruh terhadap operasional kendaraan. Berdasarkan hasil pengamatan yang dikeluarkan tiap kali kendaraan beroperasi sangatlah berpengaruh pada BOK. Biaya setoran, bahan bakar minyak (bensin), gantian ban, konsumsi untuk 2 orang (sopir dan kondektur), retribusi, perawatan lain, perawatan berkala, sebesar Rp $355.000,00 /$ hari/ trip.

\section{Produksi Pelayanan (Pnp-Km)}

Untuk menganalisis roduksi Pelayanan Jurusan Ruteng - Satar Messe terdahulu kita mengetahui terdahulu jumlah kendaraan yang beroperasi di daerah penelitian, jarak dan jumlah penumpang yang dicapai pada satuan waktu tertentu. Jumlah penumpang dalam satu ret 12 orang. Jam mulai penelitian mulai pukul 06.00 pagi sampai pukul 18.00 sore.

Tabel 9. Penumpang mobil Per Rit

\begin{tabular}{cccc}
\hline No. & No. Polisi & $\begin{array}{c}\text { Jarak Tempuh } \\
\text { KM }\end{array}$ & $\begin{array}{c}\text { Jumlah } \\
\text { Produksi pelayanan (Pnp-Km) }\end{array}$ \\
\hline 1 & EB 2822 N & $(1-35)$ & 7 \\
2 & EB.2843 E & $(1-35)$ & 8 \\
3 & EB 2392 N & $(1-35)$ & 8 \\
4 & EB 2758 E & $(1-35)$ & 7 \\
5 & EB 2791 E & $(1-35)$ & 8 \\
6 & EB 7051 E & $(1-35)$ & 10 \\
7 & EB 2359 E & $(1-35)$ & 8 \\
\hline Sumber: Hasil Survei, 2016 & &
\end{tabular}

\section{Besaran Pokok Pelayanan}

Produksi pelayanan angkutan umum merupakan besaran output yang dihasilkan dari suatu pengoperasian angkutan umum, besarannya adalah $\mathrm{Rp} 223.000,00$, Sedangkan besaran total rata-rata produksi pelayanan dari hasil survei dan setelah dianalisis adalah sebesar 8 Pnp-km. Dengan demikian, maka besarnya biaya pokok produksi pelayanan dapat diketahui, yaitu:

$$
B P P=\frac{T_{B O K}}{T_{P P}}=\frac{223.000,00}{8}=R p 27.875,00 / p n p-k m
$$

\section{Tarif Berlaku}

Penetapan tarif angkutan kota dalam Kota Ruteng dan angkutan kota kecamatan di tetapkan sesuai dengan Surat Keputusan Bupati Manggarai Nomor 36 tahun 2016 Tentang Penetapan Tarif Angkutan Penumpang Umum di Darat dalam Wilayah Kabupaten Manggarai adalah: 
a. Besarnya tarif Angkutan kota kecamatan di tetapkan jauh-dekat untuk masyarakat umum sebesar 4.500,00.- (empat ribu lima ratus rupiah). Per penumpang. Pelajar maksimal Rp 3.000,00.-( tiga ribu rupiah )

b. Besarnya tarif untuk angkutan pedesaan Rp 374.- per penumpang per kilometer

c. Besarnya tarif untuk angkutan pedesaan jurusan Ruteng Satar Mese (Puni - Iteng) Rp 13.500,00.-

\section{ATP (Ability To Pay)}

Berdasarkan hasil analisis data survei wawancara rumah tangga di kota ruteng dan Kecamatan satar mese yang menghasilkan data pendapatan keluarga (rumah tangga) dan jumlah bangkitan perjalanan menggunakan angkutan umum (minibus) Data pendapatan keluarga berdasarkan hasil survei tahun 2016 dirinci berdasarkan kelas pendapatan dan dikelompokkan sebagai berikut:

Tabel 10. Penghasilan Keluarga Berdasarkan Wawancara Rumah Tangga

\begin{tabular}{|c|c|c|c|c|c|}
\hline No & Pendapatan Keluarga (Rp) & $\begin{array}{c}\text { Frek } \\
\text { (fi) }\end{array}$ & $\begin{array}{l}\text { Nilai tengah } \\
\text { (xi) (Rp) }\end{array}$ & $\begin{array}{l}\text { Fixi } \\
\text { (Rp) }\end{array}$ & $\begin{array}{c}\text { Persentase } \\
(\%)\end{array}$ \\
\hline 1 & Rp 800.000- Rp 1.014,000 & 20 & 970.000 & 19.400 .000 & 28,57 \\
\hline 2 & Rp 1.014.000 - Rp 1.550,000 & 15 & 1.273 .000 & 19.095 .000 & 21,42 \\
\hline 3 & Rp $1.550 .000-\operatorname{Rp} 2.150 .000$ & 18 & 1.875 .000 & 33.750 .000 & 25,71 \\
\hline 4 & Rp 2.150.000 - Rp 2.553.000 & 7 & 2.381 .500 & 16.667 .000 & 10 \\
\hline 5 & Rp 2.553.000 - Rp 3.150 .000 & 5 & 2.881 .000 & 14.405 .000 & 7,14 \\
\hline 6 & Rp $3.150 .000-\operatorname{Rp} 3.500 .000$ & 5 & 3.300 .000 & 16.500 .000 & 7,14 \\
\hline & Jumlah & 70 & & 119.817 .000 & 100 \\
\hline & Rata-rata Pendapatan Keluarga & \multicolumn{4}{|c|}{$119.817 .000: 70=1.711 .671=1.712 .000$} \\
\hline
\end{tabular}

Sumber: Analisis data, 2016

Rata- rata penghasilan keluarga yang terkecil adalah Rp. 970,000, dan pendapatan rata-rata keluarga terbesar Rp.3.300.000,00 sedangkan rata-rata penghasilan keluarga perbulan Rp. 1.712.000,00 Sehingga besaran persentase pendapatan sebagai berikut:

Besaran responden penghasilan keluarga yang berada dibawah nilai rata rata adalah,

$$
\begin{aligned}
& =\frac{(1.712 .000-970.000)}{(3.300 .000 .-970,000)} \times 100 \% \\
& =32 \%
\end{aligned}
$$

Maka $32 \% \times 70=22$ orang penghasilan di bawah rata -rata dan diatas rata - rata $78 \%$ atau 45 orang. Hasil wawancara dapat diketahui pula data tentang bangkitan perjalanan dengan menggunakan angkutan kota, yang dapat dilihat pada tabel berikut ini:

Tabel 11. Data Jumlah Sampel Keluarga dan Bangkitan Perjalanan dengan Menggunakan Angkutan umum (minibus)

\begin{tabular}{ccc}
\hline Zona & Jumlah Sampel (KK) & $\begin{array}{c}\text { Jumlah Perjalanan Dengan Angkutan } \\
\text { Kota /Hari/KK }\end{array}$ \\
\hline 1 & 10 & 70 \\
2 & 15 & 70 \\
3 & 15 & 70 \\
4 & 15 & 35 \\
5 & 15 & 35 \\
\hline Jumlah & $\mathbf{7 0}$ & $\mathbf{2 8 0}$ \\
\hline Sumber: Hasil Survei, 2016 & &
\end{tabular}


Tabel 12. ATP Rata-rata Tarif Angkutan umum pedesaan jurusan Ruteng Satar Mese Tahun 2016

\begin{tabular}{|c|c|c|c|c|c|c|}
\hline No & Kelas ATP & $\begin{array}{c}\text { Frek. } \\
\text { ATP ( fi ) }\end{array}$ & $\begin{array}{c}\text { Nilai } \\
\text { tengah ( xi) }\end{array}$ & Fi.xi & $\begin{array}{c}\text { ATP Tarif Angkot } \\
(\%)\end{array}$ & $\begin{array}{c}\text { ATP Tarif angkot } \\
\text { kumulatif }(\%)\end{array}$ \\
\hline 1 & $10.000-11.000$ & 30 & 10.550 & 316.500 & 42,86 & 35,42 \\
\hline 3 & $12.000-13.000$ & 15 & 12.550 & 188.250 & 21,43 & 21,06 \\
\hline 4 & $13.000-14.000$ & 10 & 13.550 & 135.500 & 14,28 & 15,16 \\
\hline 6 & $15.000-16.000$ & 10 & 15.550 & 15.550 & 14,28 & 17,40 \\
\hline 10 & $19.000-20.000$ & 5 & 19.550 & 97.750 & 7,14 & 10,94 \\
\hline & Jumlah & 70 & & 89,3500 & & \\
\hline & Rata-rata & \multicolumn{5}{|c|}{$8.935 .000: 70=12.764 .29 \approx 12.800,00$} \\
\hline
\end{tabular}

Besaran ATP tarif angkutan yang berada dibawah nilai rata rata adalah,

$$
\begin{aligned}
& =\frac{(12.800-10.550)}{(19.550-10.550)} \times 100 \% \\
& =25 \%
\end{aligned}
$$

Maka $25 \% \times 70=18$ orang berada dibawah nilai rata-ratadan diatas rata-rata $75 \%$ atau 52 orang Hasil analisis menunjukkan bahwa WTP tarif angkutan umum pedesaan trayek kota Ruteng - Satar Mese sebesar Rp. 12.800,00 dengan rincian yaitu Rp.10.000,00 (25 \% dibawah rata) dan Rp.20.000,00 (75 \% diatas rata-rata). Hal ini menunjukkan bahwa WTP angkutan umum jurusan pedesaan pada jurusan Ruteng - Satar Mese tariff diatas Rp.12.300,00 masih layak.

\section{Perhitungan WTP}

Berdasarkan data hasil penelitian dilapangan WTP yang disajikan untuk tariff angkutan kota Ruteng Satar Messe berkisar dari Rp 10.000,00 - Rp 20.000,00, hasil seperti pada tebel dibawah ini.

Tabel 13. WTP Pengguna Angkutan umum Terhadap Tarif Angkutan umum pedesaan

\begin{tabular}{rcccc}
\hline No. & Persepsi Tarif (xi) & Frekuensi (fi) & fi.xi & Persentase (\%) \\
\hline 1 & Rp. 10.000,- & 30 & Rp. 300.000,- & 34.8 \\
2 & Rp. 12.000,- & 15 & Rp. 180.000,- & 20.93 \\
3 & Rp. 13.000,- & 10 & Rp. 130.000,- & 5.11 \\
4 & Rp. 15.000,- & 10 & Rp. 150.000,- & 17.44 \\
5 & Rp. 20.000,- & 5 & Rp. 100.000,- & 11.62 \\
\hline & Jumlah & $\mathbf{7 0}$ & Rp. 860.000,- & $\mathbf{1 0 0}$ \\
& Rata-rata & & Rp. 12.285,- $\approx$ Rp. 12.300,00 \\
\hline
\end{tabular}

Sumber: Analisis Data, 2016

Besaran WTP tarif angkutan yang berada dibawah nilai rata rata adalah,

$$
\begin{aligned}
& =\frac{(12.300-10.000)}{(20.000-10.000)} \times 100 \% \\
& =23 \%
\end{aligned}
$$

Maka $23 \% \times 70=16$ orang berada dibawah nilai rata-ratadan diatas rata - rata $77 \%$ atau 54 orang Hasil analisis menunjukkan bahwa WTP tarif angkutan umum pedesaan trayek kota Ruteng - Satar Mese sebesar Rp. 12.300,00 dengan rincian yaitu Rp.10.000,00 sebesar 22,85 \% dibawah rata dan Rp.20.000,00 sebesar $77 \%$ diatas rata-rata. Hal ini menunjukkan bahwa WTP angkutan umum jurusan pedesaan pada jurusan Ruteng - Satar Mese tariff diatas Rp.12.285,00 masih layak. Maka Tarif Angkutan Umum bagi pengguna jasa angkutan pedesaan di kabupaten Manggarai jurusan kota Ruteng - kecamatan Satar Messe adalah Rp.12. 300,00. 


\section{KESIMPULAN}

Berdasarkan hasil maka dapat disimpulkan beberapa hal antara lain:

1. BOK sebesar Rp.222.900,00 /hari/ trip. Pengguna jasa angkutan umum di kota Ruteng dan kecamatan Satar Messe adalah sebagai tarif rata-rata angkutan umum sebesar Rp. 12.800,00 Dari hari rata-rata tersebut maka di banding dengan kemauan masyarakat membayar angkutan antara $\mathrm{Rp} 10.000,00$ sampai $\mathrm{Rp} 20.000,00$ dengan rata-rata $\mathrm{Rp}$ 12.300,00 masih dalam batas normal, Sedangkan berdasarkan analisis dari biaya yang di keluarkan setiap kali kendaraan beroperasi yaitu sebesar Rp $18.600,00$ masih jauh dari tarif tetapan pemerintah daerah yaitu sebesar Rp 13.500,00

2. Kemampuan membayar untuk transportasi faktual rata-rata $\mathrm{Rp} \mathrm{12.300,00} \mathrm{Sedangkan} \mathrm{kemampuan}$ membayar terendah dari masyarakat sebesar Rp 10.000,00 dan kemampuan membayar masyarakat tertinggi sebesar Rp 20.000,00 Dari hasil tersebut menunjukkan bahwa kemampuan membayar dibawah rata-rata sebesar $23 \%$. Sedangkan kemampuan membayar di atas rata-rata sebesar $77 \%$

3. Kemauan membayar tarif dari masyarakat di Ruteng dan Kecamatan Satar Mese rata-rata adalah Rp 12.800,00 Sedangkan kemauan membayar tarif terendah sebesar Rp 10.000,00 dan kemauan membayar tarif tertinggi sebesar Rp 20.000,00 Dari hasil tersebut menunjukkan kemauan masyarakat membayar tarif dibawa rata- rata sebesar $25 \%$. Sedangkan kemauan masyarakat membayar tarif diatas rata-rata sebesar $75 \%$.

4. Berdasarkan ananalisis data pengeluaran kendaraan tiap kali beroperasi, tarif angkutan umum jurusan kota Ruteng dan kecamatan Satar Mese yang efektif perhari yaitu sebesar Rp 18.600,00 /pnp/rit

\section{DAFTAR PUSTAKA}

Badan Pusat Statistik Kabupaten Manggarai.

Bowersox, D. J. (1978). Manajemen Logistik: Integrasi Sistem-Sistem Manajemen

Hasymi, A. Distribusi Fisik dan Manajemen Material. Jakarta: Bumi Aksara.

Morlok, E. K. (1978). Pengantar Teknik dan Perencanaan Transportasi. Erlangga.

Patut, A., Gare, M.. Wora, M., (2017). Analisis Biaya Operasional Kendaraan (BOK) Angkutan Pedesaan Ruteng - Satar Mese. Skripsi S1 Universitas Flores Ende

Pedoman Teknis Departemen Perhubungan, 2002

Peraturan daerah Kabupaten Manggarai tahun 2014

Salim. (1998). Manajemen Transportasi. Penerbit Raja Grafindo Persada, Jakarta

Setijowarno, D. dan Frazila, R. B. (2001). Pengantar Sistem. Transportasi. Edisi ke-I Semarang: Penerbit Universitas Katolik Soegijapranata.

Soemarsono. (2002). Bahan Kuliah Sistem Angkutan Umum dan Barang. PPs MTS Konsentrasi

Transportasi UNDIP, Semarang

Renya Pulu. (2013). analisis kemampuan membayar tarif angkutan umum (studi kasus pada jasa angkutan di kecamatan ende utara)

UU No 22 Tahun 2009 tentang Lalu lintas dan Angkutan

Warpani, S. (1990). Merencanakan Sistem Perangkutan. Bandung: ITB. 